\title{
Tiotropium use and pulmonary function in patients with constrictive bronchiolitis
}

\author{
Uso de tiotrópio e função pulmonar em \\ portadores de bronquiolite constritiva
}

\author{
Alexandre Melo Kawassaki, Letícia Kawano-Dourado, Ronaldo Adib Kairalla
}

\section{To the Editor:}

Tiotropium, a long-acting muscarinic antagonist bronchodilator with well-established use in COPD, has recognized activity in reducing lung hyperinflation, as well as in relieving dyspnea and improving exercise capacity in this population of patients. ${ }^{(1)}$ In a recently published article, ${ }^{(2)}$ tiotropium was shown to be able to attenuate TGF- $\beta$-induced airway remodeling. In addition, the combination of albuterol and tiotropium has been shown to elicit an acute response in patients with constrictive bronchiolitis (CB) secondary to graft-versus-host disease after bone marrow transplantation, there being a significant variation

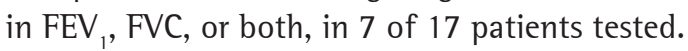
(3) Therefore, smooth muscle plays a significant role in $\mathrm{CB}$, and tiotropium might have an inhibitory activity on bronchoconstriction and airway remodeling.

Between January of 2004 and September of 2009, tiotropium was offered (HandiHaler, 18 $\mu \mathrm{g}$; once a day for 30 days) to 11 consecutive patients with CB. The diagnosis of these patients is described below. Simple spirometric tests were performed before and after tiotropium use, in accordance with the Brazilian guidelines for pulmonary function testing, ${ }^{(4)}$ and 6 patients underwent pre-treatment plethysmography.

Eight patients were female, with the mean age at diagnosis being $49 \pm 11.6$ years and the mean age at initiation of tiotropium therapy being $54.9 \pm 11.0$ years. Six patients had a history of smoking, but only 2 had a history of greater than 5 pack-years.

Nine patients had a history of significant exposure (mold, metallurgical material, birds, herbicides, paints, seeds, and plaster). Three patients had a collagen disease (rheumatoid arthritis, in 1; Sjögren's syndrome, in 1; and both, in 1); for these three patients, collagen disease was considered the major etiological factor.
All patients underwent chest $\mathrm{CT}$, which revealed direct signs of small airway disease (bronchial wall thickening, bronchiectasis, bronchiolectasis, centrilobular micronodules or opacities with a tree-in-bud pattern) in 9 patients and an indirect sign of small airway disease (mosaic attenuation) in 2 patients. ${ }^{(5)}$

Seven biopsies (six surgical biopsies and one transbronchial biopsy) were performed, all of which showed the presence of $\mathrm{CB}$. The 3 patients with rheumatic disease did not undergo lung biopsy because their clinical, functional, and CT findings were consistent with small airway disease, whereas 1 patient did not undergo biopsy because of his severe clinical status, but this patient had clinical, functional, and CT findings of CB.

The treatments instituted before the initiation of tiotropium therapy were as follows: systemic corticosteroid therapy, in 8 patients; inhaled corticosteroid therapy, in 7; long-acting $\beta_{2}$ agonist therapy, in 4; methotrexate therapy, in 4; macrolide therapy, in 3; azathioprine therapy, in 2; chloroquine therapy, in 2; and cyclophosphamide therapy, in 1. Two patients had transient clinical and functional improvement, 1 of whom used methotrexate and 1 of whom used a combination of azathioprine, prednisone, and acetylcysteine.

We analyzed 22 simple spirometric tests (2 per patient; Table 1). The median duration of tiotropium therapy was 21 days (interquartile range, 17.5-42.0), with a minimum of 14 days. The FVC and $\mathrm{FEV}_{1}$ values before and after tiotropium use are shown in Figure 1. Six patients underwent plethysmography at baseline, and all had normal or increased TLC and increased RV, suggesting air trapping, consistent with the clinical diagnosis of CB. After the initiation of tiotropium therapy, $\mathrm{FEV}_{1}$ increased from $870 \pm 310 \mathrm{~mL}$ to $1,060 \pm$ $350 \mathrm{~mL}(18.7 \pm 9.2 \% ; \mathrm{p}=0.0002)$ and FVC increased from $1,520 \pm 500 \mathrm{~mL}$ to $1,800 \pm 420$ 
Table 1 - FVC and FEV , before and after the initiation of tiotropium therapy in the patients studied and percent change. ${ }^{a}$

\begin{tabular}{ccccccc}
\hline Patient & $\begin{array}{c}\text { Pre-therapy } \\
\text { FEV }_{1}, \mathrm{~L}\end{array}$ & $\begin{array}{c}\text { Post-therapy } \\
\text { FEV }_{1}, \mathrm{~L}\end{array}$ & $\begin{array}{c}\Delta, \% \\
\text { Pre-therapy } \\
\text { FVC, L }\end{array}$ & $\begin{array}{c}\text { Post-therapy } \\
\text { FVC, L }\end{array}$ & $\Delta, \%$ \\
\hline 1 & $0.99(39)$ & $1.41(56)$ & 30 & $1.69(57)$ & $2.06(70)$ & 18 \\
2 & $1.09(55)$ & $1.35(68)$ & 19 & $1.39(56)$ & $1.72(70)$ & 19 \\
3 & $0.46(22)$ & $0.51(24)$ & 10 & $1.10(42)$ & $1.18(45)$ & 7 \\
4 & $1.13(46)$ & $1.22(50)$ & 7 & $2.53(88)$ & $2.51(88)$ & -1 \\
5 & $0.54(17)$ & $0.77(23)$ & 30 & $0.89(22)$ & $1.61(40)$ & 45 \\
6 & $0.98(27)$ & $1.19(37)$ & 18 & $1.85(42)$ & $2.25(57)$ & 18 \\
7 & $1.21(63)$ & $1.43(74)$ & 15 & $1.85(79)$ & $2.11(89)$ & 12 \\
8 & $0.75(39)$ & $0.88(46)$ & 15 & $1.33(58)$ & $1.45(63)$ & 8 \\
9 & $1.29(60)$ & $1.42(66)$ & 9 & $1.88(72)$ & $1.98(76)$ & 5 \\
10 & $0.42(13)$ & $0.51(16)$ & 18 & $0.92(24)$ & $1.24(33)$ & 26 \\
11 & $0.66(26)$ & $1.02(37)$ & 35 & $1.24(41)$ & $1.64(51)$ & 24 \\
Mean & $0.87(37)$ & $1.06^{*}(45)$ & 19 & $1.52(53)$ & $1.80^{* *}(62)$ & 17 \\
\hline
\end{tabular}

avalues expressed as $n(\%) .{ }^{*} p=0.0002 .{ }^{* *} p=0.0011$.
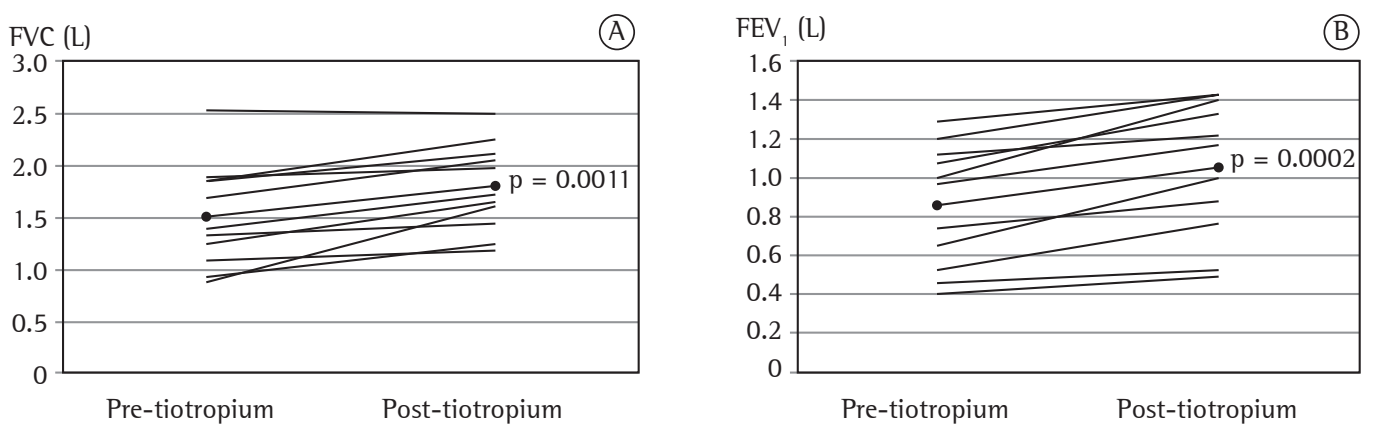

Figure 1 - Variation in $\mathrm{FEV}_{1}$ (in A) and in FVC (in B) before and after tiotropium use. The darker lines represent the mean values.

$\operatorname{mL}(16.5 \pm 12.6 \% ; p=0.0011)$, whereas the $\mathrm{FEV}_{1} / \mathrm{FVC}$ showed no significant change (from $0.57 \pm 0.11$ to $0.58 \pm 0.12 ; p=0.46$ ). Figure 1 shows the change in FVC and FEV for each patient, as well as the mean values for the group.

The mean functional gain was $280 \mathrm{~mL}$ or $16.5 \%$ for FVC and $190 \mathrm{~mL}$ or $18.7 \%$ for $\mathrm{FEV}_{1}$, values that are similar to those reported in patients with COPD. ${ }^{(1)}$ Only 2 of the 11 patients did not show improvement of greater than $100 \mathrm{~mL}$ in $\mathrm{FEV}_{1}, \mathrm{FVC}$, or both, and it was impossible to predict the presence of response solely on the basis of clinical characteristics.

Our findings show that patients with $\mathrm{CB}$ have prolonged functional improvement with the use of a drug with a recognized anticholinergic effect, suggesting that acetylcholine plays a role in the pathophysiology of CB through bronchial smooth muscle contraction. To our knowledge, this is the first case series showing spirometric improvement with tiotropium use in patients with CB of different etiologies, which justifies the need for larger and longer studies to evaluate the impact of tiotropium bromide use on the progression of CB. ${ }^{(3,6)}$

\section{Alexandre Melo Kawassaki}

Physician, Interstitial Disease Group, São Paulo State Cancer Institute, University of São Paulo School of Medicine Hospital das Clínicas; and Pulmonologist, Hospital 9 de Julho, São Paulo, Brazil

Letícia Barbosa Kawano-Dourado Physician, Interstitial Disease Group, Heart Institute, University of São Paulo School of Medicine Hospital das Clínicas, São Paulo, Brazil 


\section{Ronaldo Adib Kairalla}

Assistant Professor, Interstitial Disease

Group, Heart Institute, University of

São Paulo School of Medicine Hospital das Clínicas; and Pulmonologist, Hospital Sírio-Libanês, São Paulo, Brazil

\section{References}

1. Celli B, ZuWallack R, Wang S, Kesten S. Improvement in resting inspiratory capacity and hyperinflation with tiotropium in COPD patients with increased static lung volumes. Chest. 2003;124(5):1743-8. http://dx.doi. org/10.1378/chest.124.5.1743 PMid:14605043

2. Oenema TA, Mensink G, Smedinga L, Halayko AJ, Zaagsma $\mathrm{J}$, Meurs $\mathrm{H}$, et al. Cross-talk between transforming growth factor- $\beta_{1}$ and muscarinic $M_{2}$ receptors augments airway smooth muscle proliferation. Am J Respir Cell Mol Biol. 2013;49(1):18-27. http://dx.doi.org/10.1165/rcmb.201202610C PMid:23449734

3. Barisione G, Bacigalupo A, Crimi E, Brusasco V. Acute bronchodilator responsiveness in bronchiolitis obliterans syndrome following hematopoietic stem cell transplantation. Chest. 2011;139(3):633-9. http://dx.doi. org/10.1378/chest.10-1442 PMid:20724742

4. Sociedade Brasileira de Pneumologia e Tisiologia. Diretrizes para testes de função pulmonar. J Pneumol. 2002;28(Suppl 3):S1-S238.

5. Devakonda A, Raoof S, Sung A, Travis WD, Naidich D. Bronchiolar disorders: a clinical-radiological diagnostic algorithm. Chest. 2010;137(4):938-51. http://dx.doi. org/10.1378/chest.09-0800 PMid:20371529

6. Matsuyama W, Yamamoto M, Machida K, Oonakahara K, Watanabe M, Higashimoto 1, et al. A case of bronchiolitis obliterans syndrome successfully treated by tiotropium bromide [Article in Japanese]. Nihon Kokyuki Gakkai Zasshi. 2006;44(5):404-9. PMid:16780100 